\title{
Evaluating Sediment Production Caused by the Lithology of the Geological Formations in Sedimentary Basins (Case Study: Lali Area, Khuzestan, Iran)
}

\section{Abdolreza Alijani', Nader Kohansal Ghadimvand'2, Mohsen Aleali1 ${ }^{*}$, Mohammad Reza Espahbod ${ }^{3}$, Ali Meysami ${ }^{4}$}

\author{
${ }^{1}$ Department of Geology, Science and Research Branch, Islamic Azad University, Tehran, Iran \\ ${ }^{2}$ Department of Geology, North Tehran Branch, Islamic Azad University, Tehran, Iran \\ ${ }^{3}$ North Tehran Branch, Islamic Azad University, Tehran, Iran \\ ${ }^{4}$ Department of Geology, Shahr-e-Ray Branch, Islamic Azad University, Tehran, Iran \\ Email: arz.alijani@yahoo.com,n-kohansalghadimvand@iau-tnb.ac.ir, ^aleali.mohsen@gmail.com,dr.ESPAHbod@gmail.com, \\ azarmirazi@gmail.com
}

How to cite this paper: Alijani, A., Ghadimvand, N.K., Aleali, M., Espahbod, M.R. and Meysami, A. (2016) Evaluating Sediment Production Caused by the Lithology of the Geological Formations in Sedimentary Basins (Case Study: Lali Area, Khuzestan, Iran). Open Journal of Geology, 6, 996-1012.

http://dx.doi.org/10.4236/ojg.2016.69075

Received: July 20, 2016

Accepted: August 30, 2016

Published: September 2, 2016

Copyright $\odot 2016$ by authors and Scientific Research Publishing Inc. This work is licensed under the Creative Commons Attribution International License (CC BY 4.0).

http://creativecommons.org/licenses/by/4.0/ (c) (i) Open Access

\section{Abstract}

As sediments are produced and accumulated in sedimentary basins especially in dams' reservoirs and they highly affect the reservoirs life span, it is essential to scrutinize the effect of lithology and types of geological formations of an area on the life span of reservoirs specifically from the viewpoints of the erodability of these formations due to their lithology type. Lali area, Khuzestan, Iran and the water catchment of the intended area (based on geological situation and Taraz dam situation) are placed in the sedimentary-structural zone of the folded Zagros. The method of this research is based on analyzing the topography and geology maps and field work in order to identify the lithology of the geological formations. In fact, the amount of its erodability has been characterized by the type of the geological formations. The current research aims at putting the geological results, lithological data of the formations types and the outcrop of the soil-lithological units together in order to evaluate the sedimentary and erosive factors of these units and precisely identify the area's geological formations to remove the ambiguities in this issue. Studies indicate that formations made of looser gypsum and marl like Pabde-Gurpi and Gachsaran are exposed to more sedimentation and erosion than the formations made of compacted lime stone and conglomerate with silica-lime cement such as Bakhtiary and Asmari formations and the sand stones of Aghajari formation reveal the moderate to high resistance. Thus, the lithological identification of the formations, the type of sedi- 
ments and their looseness and hardness contribute to detect the amount and type of deposits entering into the dam reservoir. The type and amount of these transported and deposited sediments are assessed to predict more suitable optimized ways to exploit dams' reservoirs.

\section{Keywords}

Geological Formations, Lali Area (Khuzestan), Sedimentation, Settlement, Lithology

\section{Introduction}

The case study is situated in Lali area, Khuzestan province in Iran and $200 \mathrm{~km}$ far from the north of Ahwaz province. From geological point of view, it is placed in the sedimentary structural zone of the folded Zagros. It is expected that this zone mainly holds formations of Bakhtiary conglomerate, Aghajari sand stone, Marl of Mishan, Gachsaran gypsum and Asmari lime. Furthermore, there are outcrops like Pabdeh- Gurpi, etc. [1]. Various blocks of these layers are separated and transported into the downstream of river in Lali area because of weathering and erosion factors on the area's geological formations especially on the upstream of the water catchment based on the lithology type of the rock layers. The blocks range from angular pebbles to angular to semi-angular and rounded to semi-rounded fine grains [2]. These coarse grains of alluvia sediments mainly originate from Asmari lime rock formations of Aghajari and Bakhtiary conglomerate. This research profoundly analyzes the types of such geological formations. This area has been remarkably affected by Dezful embayment (DE = Dezful Embayment) which its main folded structure has been Valachin orogeny. Figure 1 displays the geographical situation and the accessible ways to Lali area.

Since sediment and sedimentation are the most essential factors in civil projects and establishments especially in dams' reservoirs, lots of studies have been done in this regard. However, some important geological and sedimentary points have been ignored such as affective factors on sedimentation, lithological type and the geological formations of the intended area producing and increasing the amount of sediments [3]. Furthermore, identifying the specifications of rock outcrops and sedimentary type have been considered.

\section{Review of Literature}

Several base studies have been done in this regard, for example, various investigations have revealed the relationship between sediments with the type of the geological formations of the area and the amount of their erodability. Norlan (1986) assessed the ratio of erodible formations as the origin of floating load in California [4]. Kasimir, et al. (1990) demonstrated that small basins with the ratio of looser formations affect the floating sedimentary load [5]. Khojeini and Nezhadha Shami (1998) indicated the effect of erodible formations on sediment production in Taleghan, Iran water catchment [6]. 


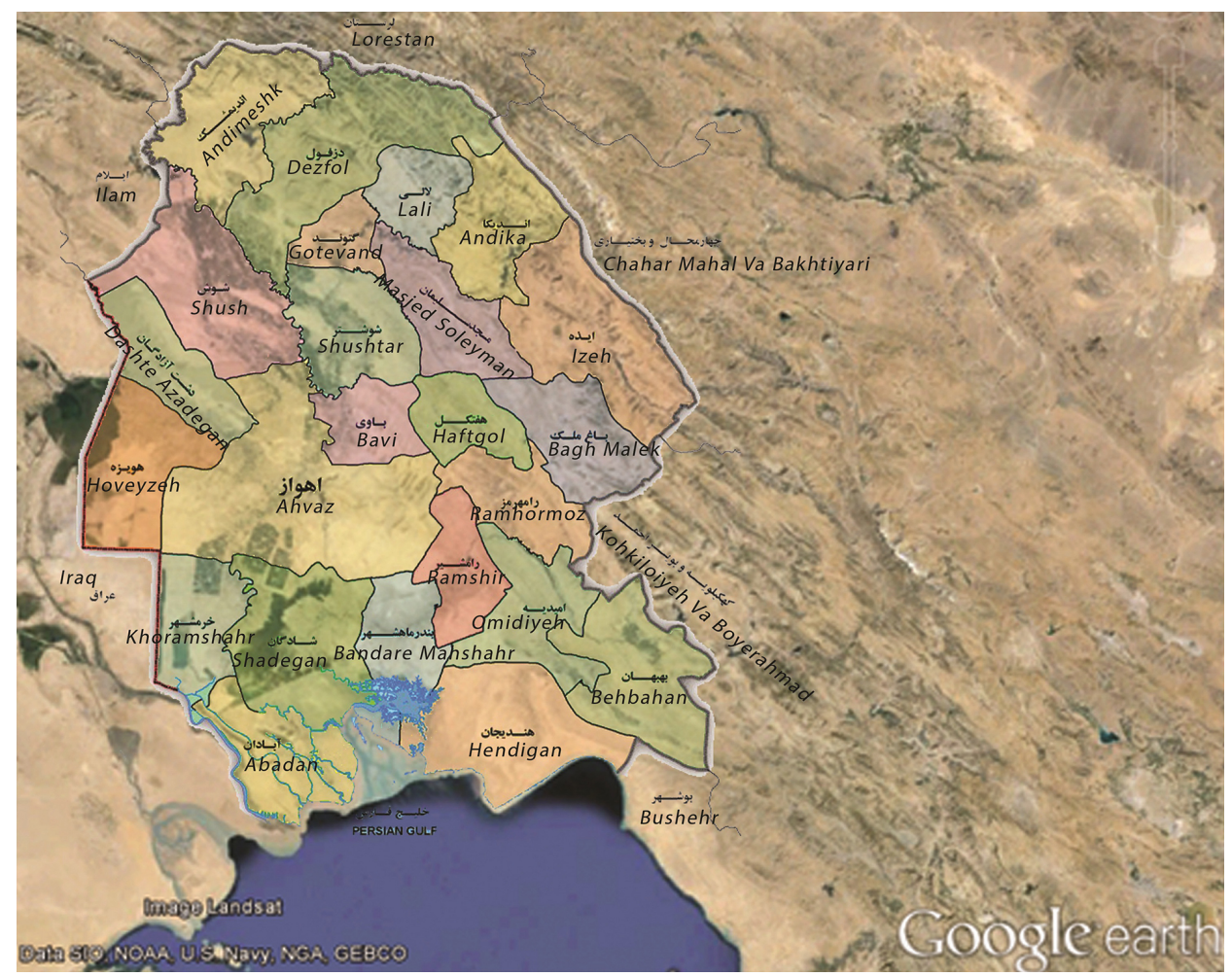

Figure 1. The geographical situation and the accessible ways to Lali area, from Google earth.

Aminsobhani (1998) proved the impact of sedimentation on marl and shale erodible formations in Namak Lake of Iran [7]. These studies demonstrate the amount of sensitivity to erosion in geological formations and sedimentations in the basins. Furthermore, erodible geological formations highly affect sedimentation in water catchments. Moreover, the amount of sedimentation relies on the surface area of the water catchment basin and the surface ratio of the erodible formations out of the whole basin. In case there are formations with looser lithology, the amount of sedimentation will be enhanced.

\section{Methodology}

Field work studies on the geological formations of the area specify both the lithology type of the area and the resistance of this type of lithology due their physico-mechanical properties of the rock layers. The type of the geological formations and the lithology of these formations have been specified by analyzing the geology and topography maps of the water catchment upstream of the sedimentary basin and field work in Lali area. The method of this research is based on analyzing the topography and geology maps and field work in order to identify the lithology of the geological formations. In fact, the amount of its erodability has been characterized by the type of the geological formations

According to various geological formations, changes in the types of layers, different physico-chemical especially mechanical properties and the erodability and strength of 
the soil and rock masses, it is demonstrated that these geological formations are able to produce sediment. In this research, these specifications are first identified and then the area's geological formations are scrutinized from the viewpoint of the potential of producing less or more sediments [8]. Holistically, it is specified that formations with low erosion and more strength are less probable to produce sediment. In contrast, formations with high erosion and less strength can produce sediment [9].

\section{Geological Setting}

The erosion amount of the lithological units and sediments transportation to sedimentary basins are recognized as one of the key factors determining the geomorphological properties, the accumulation specifications and the replacement of the sedimentary masses [10]. From morphological point of view, this situation is placed approximately $250 \mathrm{~m}$ away from the crossing point of Harkesh and Taraz Rivers and it has a strait shape made by the floods from Harkesh River. Figure 2 indicates a view of Taraz Dam situated in the dam axel in which the morphological extension and river bed of Harkesh River (HR). In addition, Figure 3 features out a view of the porous lime stone (I). there inter-beds inside gypsums of Gachsaran formation $(\mathrm{Mg})$ which are seen as small and big blocks (up to $2 \mathrm{~m}$ diameter) on the ground.

The conditions of its extensions both at the right and left sides are as below:

- Right side extension: The slope of the extensions from top to bottom include: $70^{\circ}$ above the heights as long walls and declining from the bottom of the wall to the alluvia terraces of the lower level $\left(17^{\circ}\right)$. It is scored that the slopes become less than $5^{\circ}$.

- Left side extension: $75^{\circ}$ of the higher levels are like long walls extending to the downstream, trenches and road way, the extension slope is $35^{\circ}-40^{\circ}$.

The sedimentary process influences the erosion index of the area's units and the determination of the sediment abundance percentage of each unit in the area.

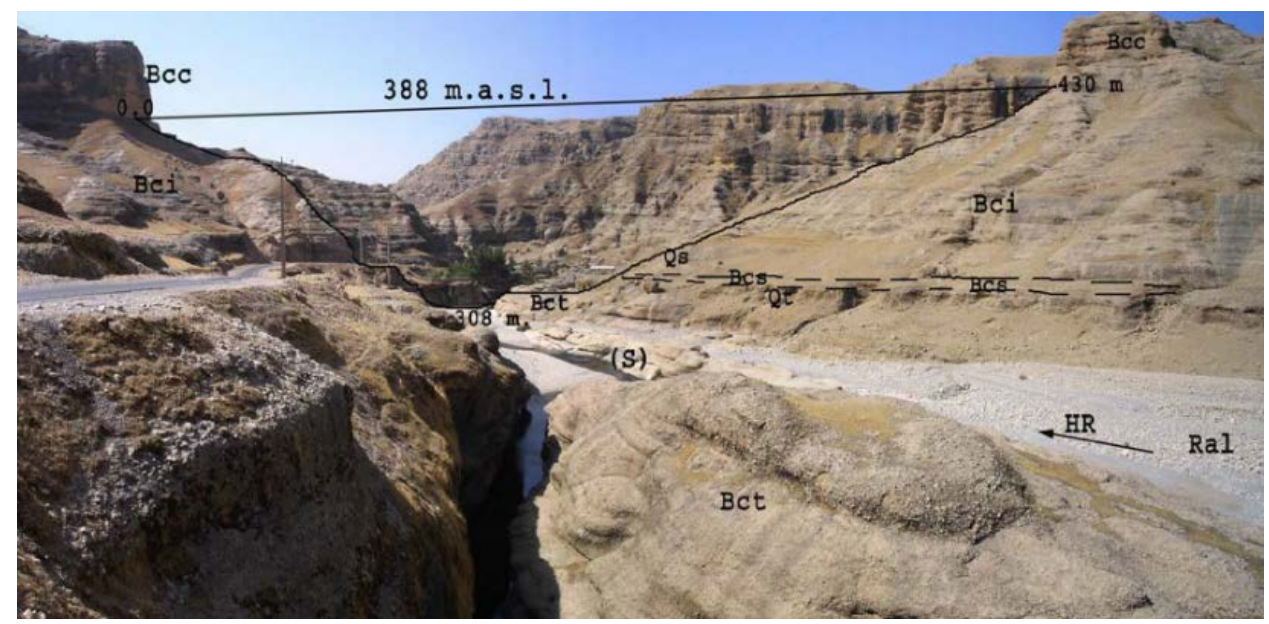

Figure 2. A view of Taraz Dam situated in the dam axel in which the morphological extension and river bed of Harkesh River (HR) clearly shown. The alluvium of the river bed-Qt-the old alluvium as alluvia terrace, S-foundation outcrop (Sarsen), Bcc, Bci, Bcs and Bct are the conglomerate units of Bakhtiary formation. The layers are somehow horizontal. 


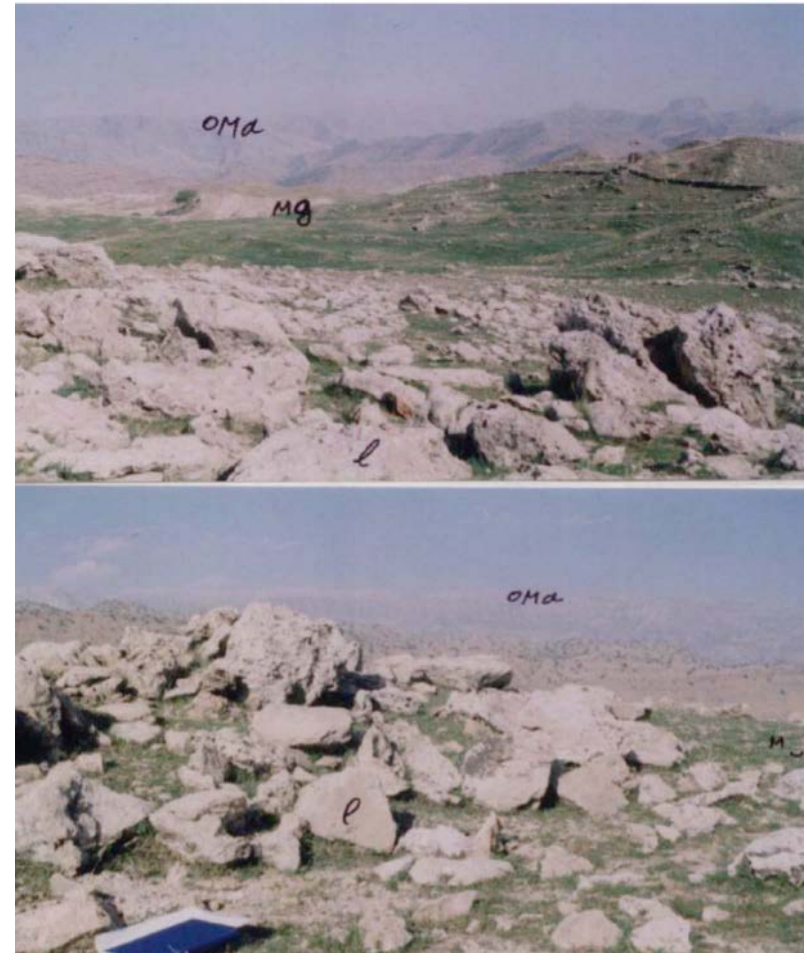

Figure 3. A view of the porous lime stone (I). there inter-beds inside gypsums of Gachsaran formation (Mg) which are seen as small and big blocks (up to $2 \mathrm{~m}$ diameter) on the ground.

The general appearance of the morphological specifications is as the following.

Lime stone pebbles have surrounded parts of the conglomerate bed rock at the river bed and the foundation outcrop is observed and the high level of the bed rock of the alluvia is indicated.

The right side extension is more even than the left one for the sake of streams specifically in the upper part of the left extension [11].

Both extensions are bedded in the conglomerate layers of Bakhtiary formation and are somehow horizontal.

The old left alluvia of Harkesh River are observed as a long strip on the right side of the river, but they have become like alluvial terraces.

Above $388 \mathrm{~m}$, there are thick conglomerates on both extensions which are long and their height is scored more than $20 \mathrm{~m}$. The extension of macro joints can be measured in the conglomerate layers within distance more than $1-2 \mathrm{~m}$.

\section{Soil and Lithological Masses at the Geological Situation}

The lithological masses observed as thick layers of Bakhtiary conglomerate outcrops make more than $95 \%$ of the conglomerate aggregates of Asmari and/or older lime stones. Generally, they are rounded to semi-rounded. More precise analyses on the folded conglomerate Bakhtiary rocks indicate the following points: Coarse grain layers (the average diameter of $0.7 \mathrm{~cm}$ ) are made of lime stones and wall making layers. The grains are paired from bad to moderate and some of them have been displaced. Some 
layers hold finer grains (the average diameter of $5 \mathrm{~cm}$ ) and their matrix is lime sand. As sand stone and silt are more than the coarse ones in these layers, some of them hold sand stones with cross-bedding [12]. There are several red inter-layers of silt and sometimes sand stone in the inter-beds of conglomerate which their width isn't more than $1 \mathrm{~m}$, they are exposed to more erosion than conglomerate layers and they have outcrops in the extensions of topography.

In addition, there are coarse grains of alluvia as big as pebbles, sand, gravel and stone blocks at the river bed. It seems that its width doesn't reach to more than $1 \mathrm{~m}$. Holistically, more than $90 \%$ of them are lime stone grains mainly belonging to the separated blocks of Asmari lime formation on the upstream of this water catchment.

Hence, the type of blocks forming these pebbles affects erosion and sedimentation. So, erosion, sediments transportation in sedimentary basins and the sedimentation of these deposits in dams' reservoirs decrease the life span of dams [13]. It is essential to study the effective processes on sedimentation. Figure 4 shows the lithology, structure and geology map of the lithological-soil units of this position.

Table 1 summarizes the general specifications of lithological units in Lali area.

\section{The Specifications of the Structural Geology of Lali Area}

The water catchment expansion of rivers flowing through the area specially Talug and Shur rivers are situated in the sedimentary- structural zone of the folded Zagros (see Figure 5). Therefore, the general characteristics of this zone are as below.

There are asymmetric simple folds with different slope sides. In another word, their axial surface is different. However, some of the folds less than $10-20 \mathrm{~km}$ might be vertically close to one another. As this folding style gets closer to the high Zagros, it is changed from the south-east to the north-east [14]. As expected, more irregularities are observed. Since the intended expansion is far from the high Zagros, the folds are very simple and the sedimentary layers aren't remarkably extended.

There are few faults and the length of the main ones are more than $10 \mathrm{~km}$ which all show the same trend of Zagros. They direct a deep slope toward north-east (more than $65^{\circ}-70^{\circ}$ ). Figure 6, Figure 7, Figure 8 and Figure 9 represent the distribution pattern and dispersion of the amount of fractures and the joints in the right and left sides of Harkesh River in Lali area, Khuzestan caused by tectonic activities and the effects of the erodability ratio of the formations in the area on th Schmidt network (STERIONET) or Rose diagram. As observed, most of the fractures and sediment production have been mostly concentrated at the NW-SE of the STRERIONET. It is concluded they are along with the folds of Zagros chain of mountains in Iran, as expected.

Important faults affecting the geological structure of Lali area include: Dali fault, Sarvand-Meyboran fault (SMF), Durak fault (DRF), Jagiri fault (JF), Lali Fault (LF), Qale Khaju fault (QKF), Cheshmeh Shirin fault (CSF) fault and Chiti fault (CF).

Table 2 illustrates the specifications of all faults in the expansion of $300 \mathrm{~km}$ in Lali area. As observed, most of the faults closer to the position are the normal ones which are gradually converted into inverse and thrust- compressive faults [15]. 

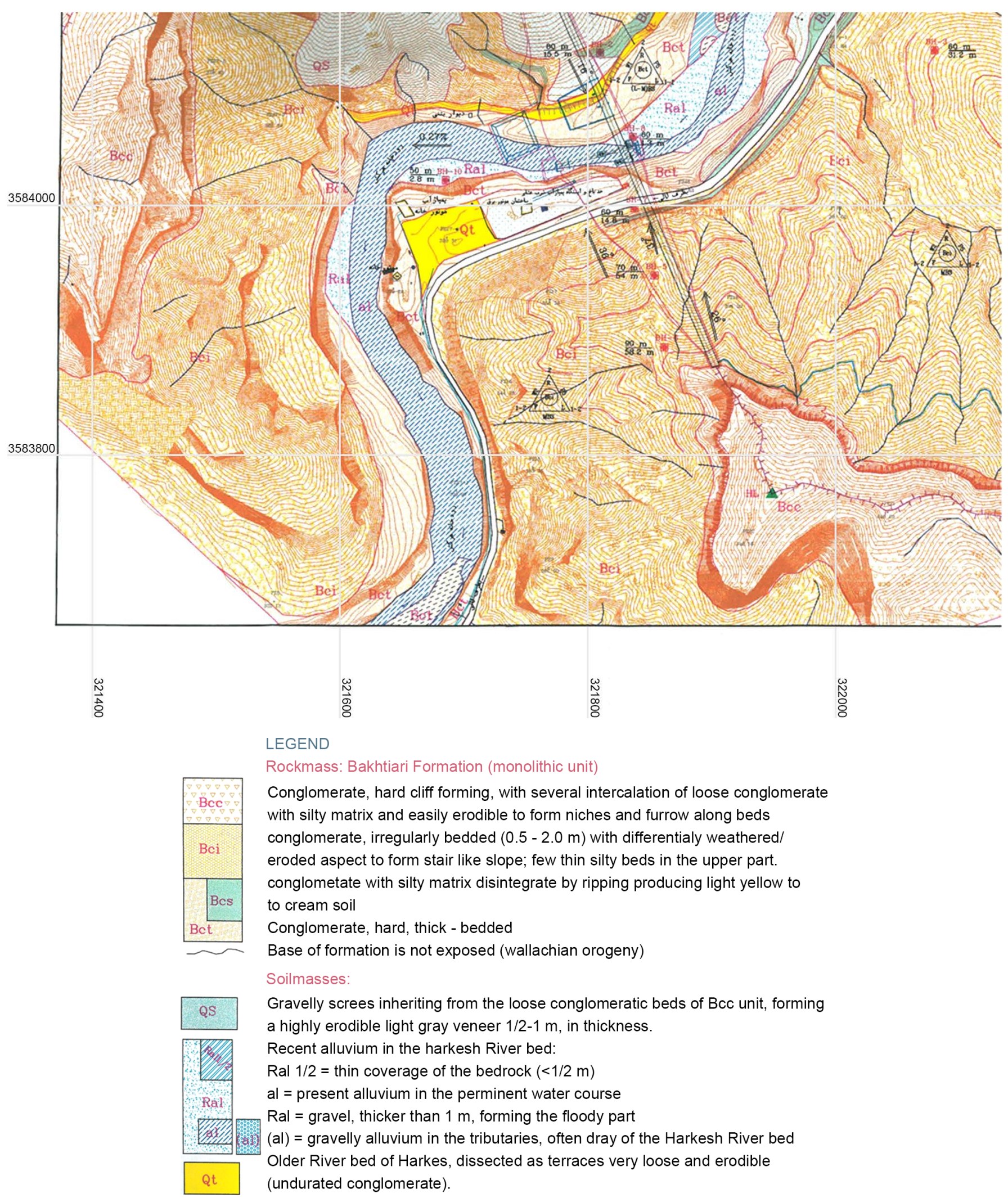

Figure 4. The geological map (T/GE/1), Lali area, Khuzestan, Iran quoted from the geology report of Ab-Niru Consulting Engineering Company, 2005. 
Table 1. The general specifications of Lithological units in Lali area.

\begin{tabular}{|c|c|c|c|c|}
\hline Formation & $\begin{array}{l}\text { Prominent } \\
\text { lithology }\end{array}$ & $\begin{array}{l}\text { Outcrop in the } \\
\text { water catchment }\end{array}$ & $\begin{array}{c}\text { Visible } \\
\text { height }(\mathrm{m})\end{array}$ & Specifications \\
\hline Daryan & $\begin{array}{l}\text { Lime stone with } \\
\text { good layers }\end{array}$ & $\begin{array}{l}\text { Taluk (Sar Tang } \\
\text { Baba Ahmad) }\end{array}$ & $100-90$ & Small out crop \\
\hline Kajdomi & Dark shales & Taluk & $200-150$ & Impermeable \\
\hline Sarvak & Gray lime stone & Chain of stone-valley & $>550$ & $\begin{array}{c}\text { Karesti to some } \\
\text { extend }\end{array}$ \\
\hline Pabde-Gurpi & Shale and marl & Chain of stone-valley & 800 in total & $\begin{array}{c}\text { Low permeability-high } \\
\text { erodability }\end{array}$ \\
\hline Tel Zang & Marl lime stone $50-70$ & Taluk, Sur I and Taraz & $70-50$ & Step making \\
\hline Amiran & $\begin{array}{l}\text { Green shale, sand } \\
\text { stone and cutting } \\
\text { conglomerate }\end{array}$ & Taluk & $250-200$ & Hard and brittle \\
\hline Kashkan & $\begin{array}{l}\text { Red marl, sand stone } \\
\text { and conglomerate }\end{array}$ & Shur I & 200 & $\begin{array}{c}\text { Low permeability-high } \\
\text { erodability }\end{array}$ \\
\hline Asmari & $\begin{array}{l}\text { Beige lime stone and } \\
\text { marl in upper part }\end{array}$ & Chain of stone-valley & 400 & $\begin{array}{c}\text { Higher part of } \\
\text { Karesti }\end{array}$ \\
\hline Gachsaran & gypsum & Shur II & $>1000$ & Impermeable-solvable \\
\hline Mishan & Low amount of marl & Shur I, Chiti & 100 & Very low permeability \\
\hline Aghajari & $\begin{array}{l}\text { silt, sand stone and } \\
\text { conglomerate }\end{array}$ & $\begin{array}{c}\text { Shur I, Shur II, Chiti, } \\
\text { Gazi and Taraz }\end{array}$ & $>1000$ & $\begin{array}{c}\text { Low permeability-high } \\
\text { erodability }\end{array}$ \\
\hline Bakhtiari & conglomerate & Taraz, Shur II, etc & $>350$ & Wall maker in marl \\
\hline
\end{tabular}

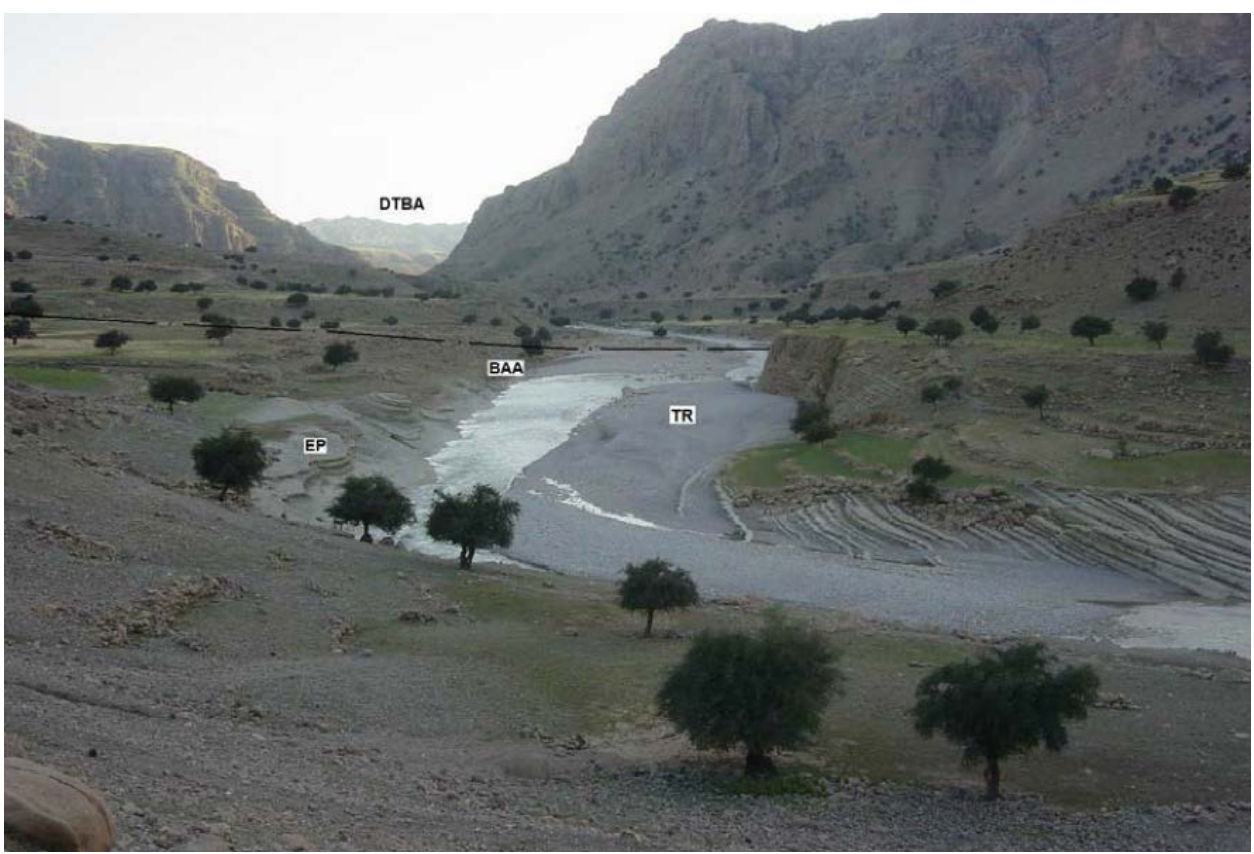

Figure 5. Apart of Talug River (TR) has outcrop between Sartang and Dom Baba Ahmad (BTBA) in which marl lime stones have been emerged. 


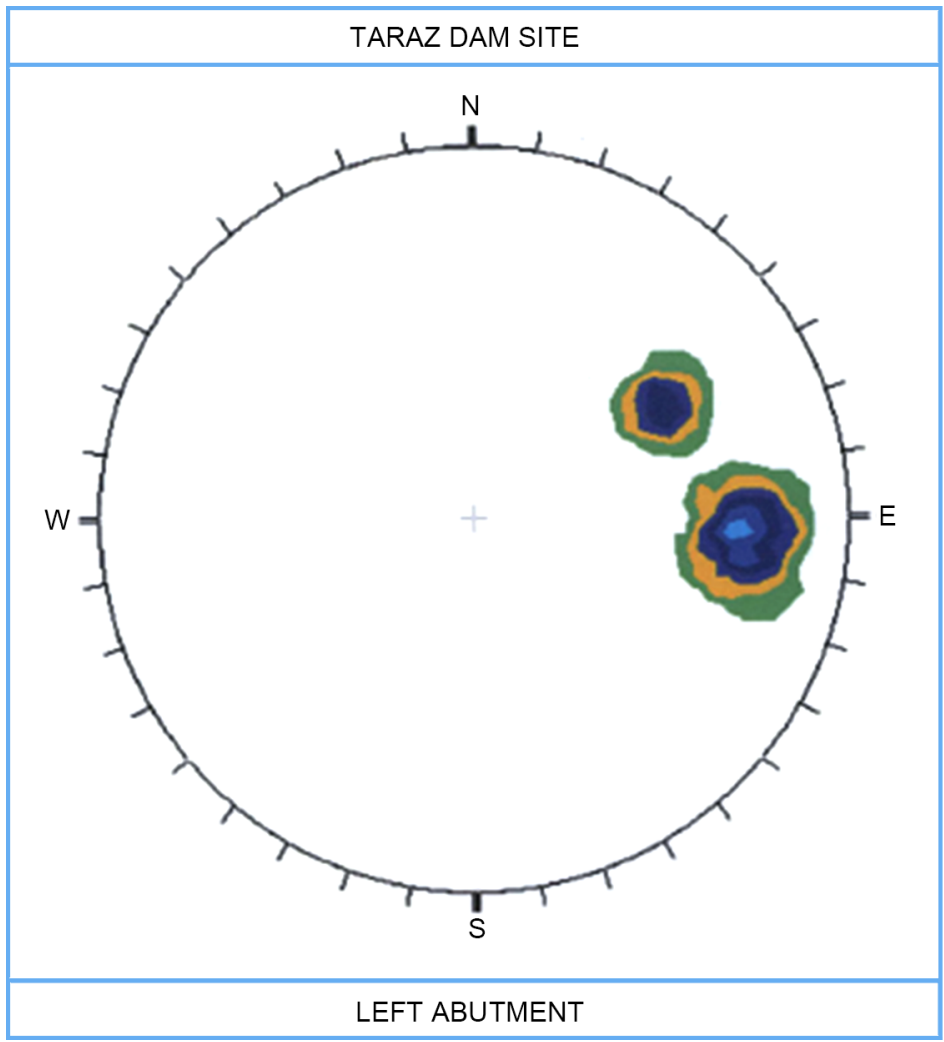

CONTOUR PLOT

SCHMIDT POLE CONCENTRATIOS

$\%$ of total per

$1.0 \%$ area

$\square<\begin{array}{lll}< & 0 & \% \\ < & 6 & \% \\ < & 12 & \% \\ < & 18 & \% \\ < & 24 & \% \\ < & 30 & \% \\ < & 36 & \% \\ < & 42 & \%\end{array}$

EQUAL ANGLE

LNR. HEMISPHERE

84 POLES

84 ENTRIES

NO BIAS

CORRECTION

Figure 6. The situation of the fractures and joints concentration on the left abutment in Lali area.

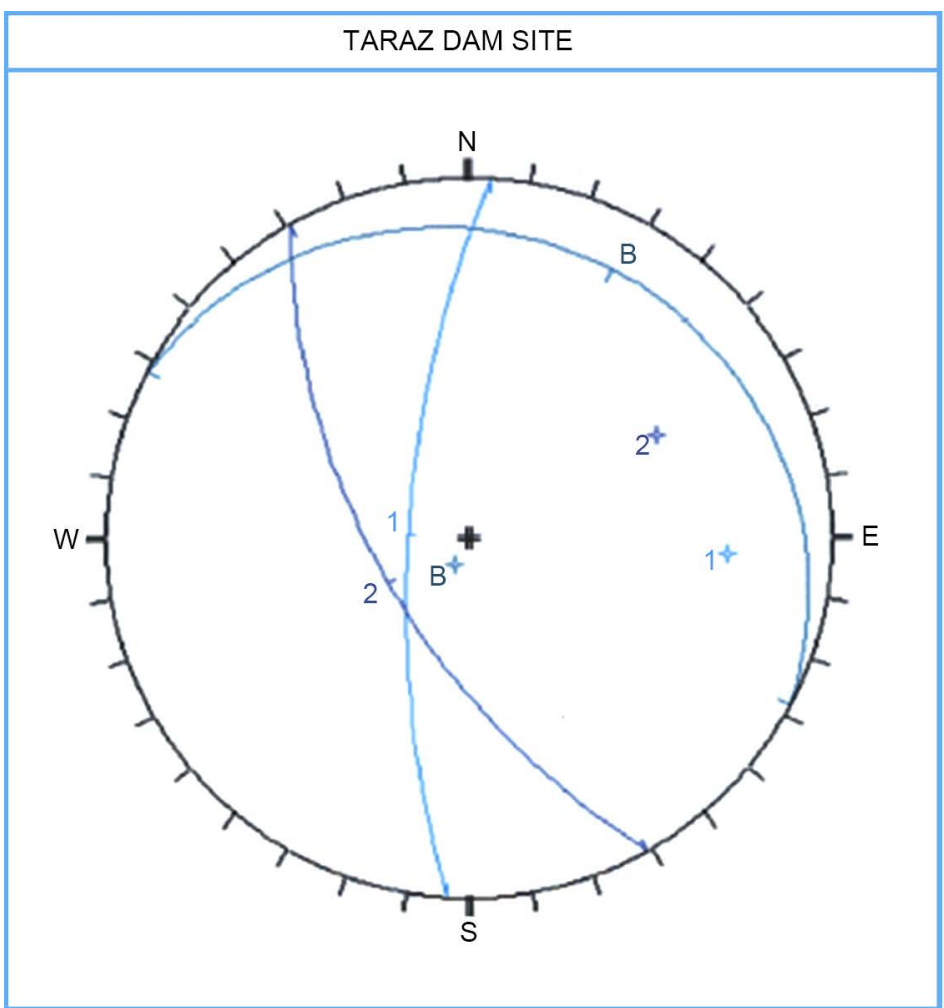

MAJOR PLANES

ORIENTATIONS

\# DIP/DIR

$1 \quad 71 / 274$

$2 \quad 61 / 241$

B $\quad 10 / 028$

EQUAL ANGLE LNR.HEMISPHERE

Figure 7. The equal curves of joints poles and fractures in the geological formations in Lali area. 

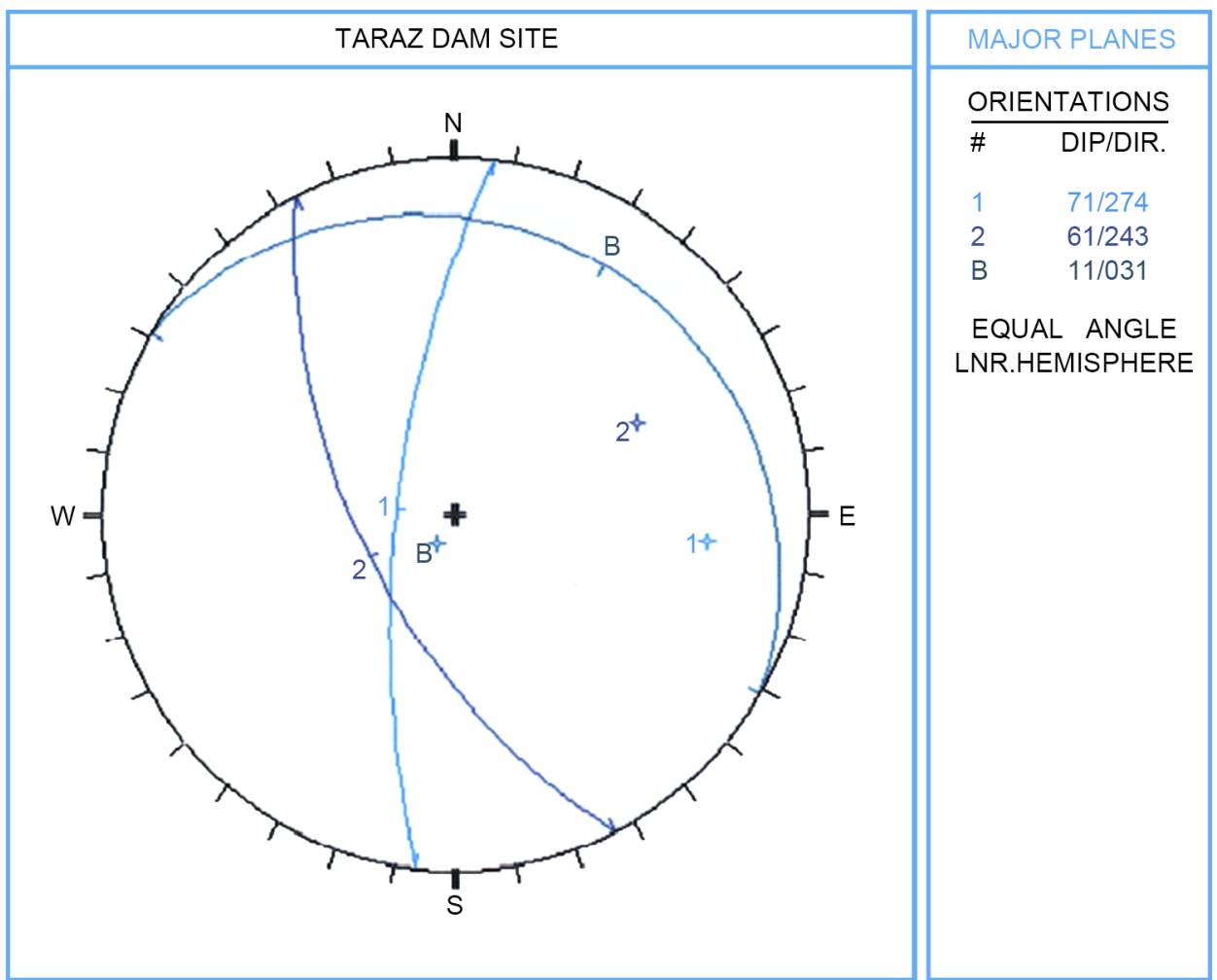

Figure 8. The equal curves of joints poles and fractures in the geological formations in Lali area.

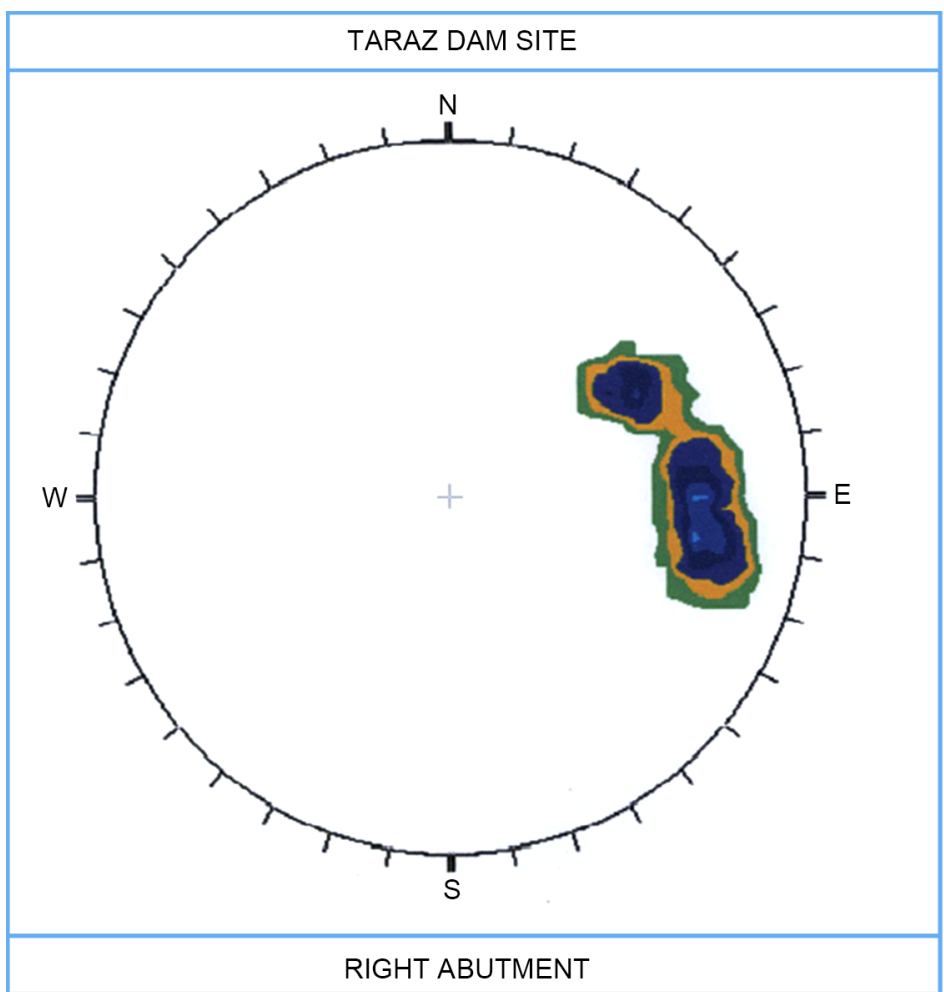

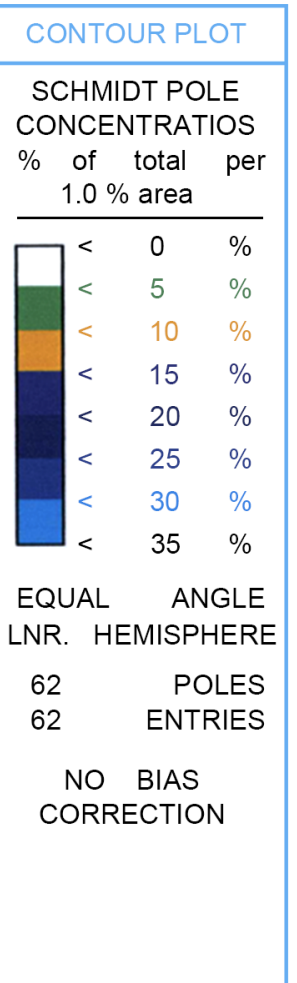

Figure 9. The situation of the fractures and joints concentration on the right abutment in Lali area. 
Table 2. The specifications of faults in the expansion of $300 \mathrm{~km}$ in the Lali area.

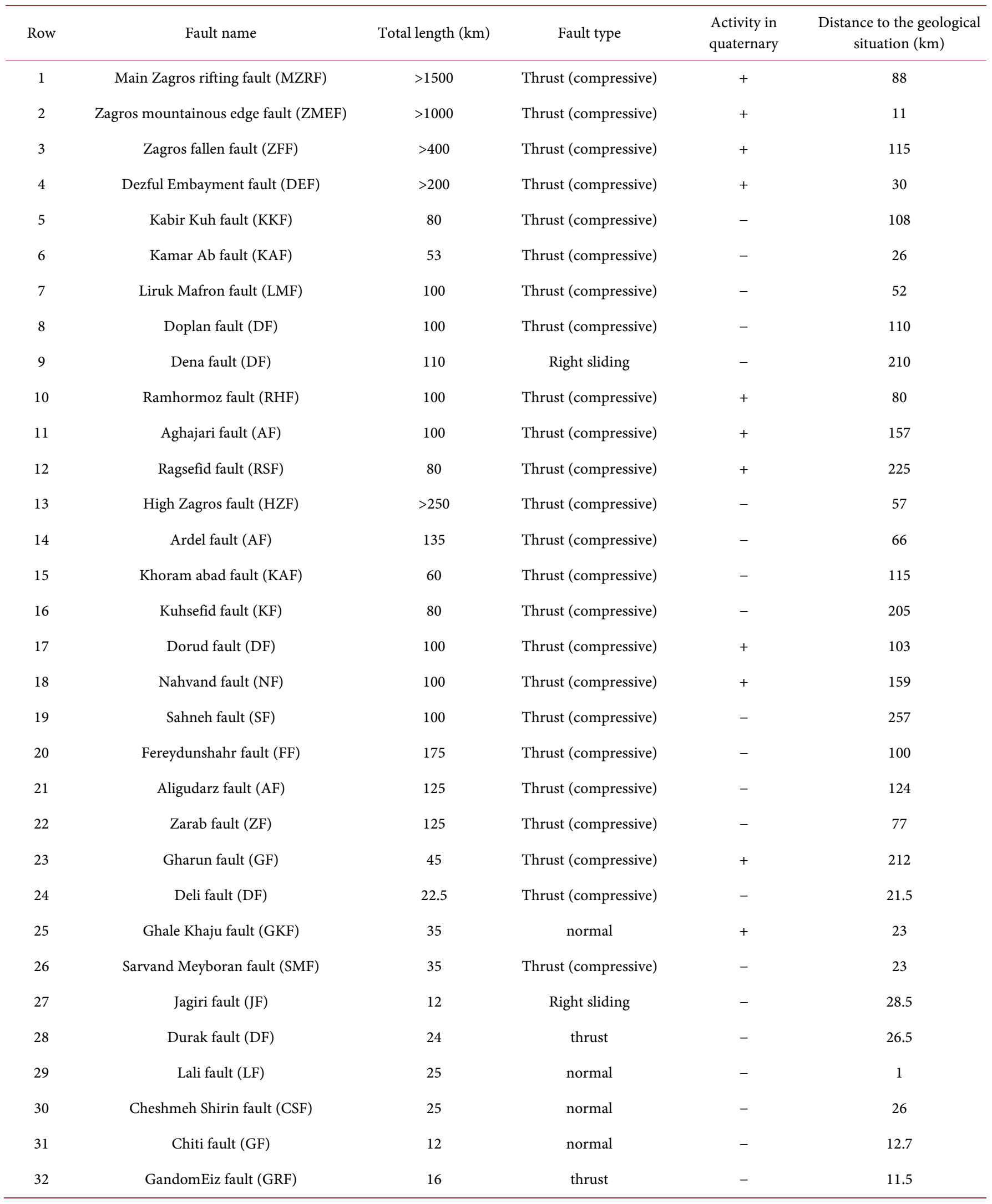




\section{Discussion}

From geological point of view, Lali area is situated in the structural zone of the folded Zagros and it affects other structures. It is expected that this zone mainly holds formations of Bakhtiary conglomerate, Aghajari sand stone, Marl of Mishan, Gachsaran gypsum and Asmari lime. Furthermore, there are outcrops like Pabdeh-Gurpi. Various blocks of these layers are separated and transported into the river downstream in Lali area because of weathering and erosion factors on the area's geological formations. Kasimir, et al. (1990) demonstrated that small basins with the ratio of looser formations affect the floating sedimentary load. Khojeini and Nezhadha Shami (1998) indicated the effect of erodible formations on sediment production in Taleghan, Iran water catchment. Ghami Arusmahalleh and Aminsobhani (1998) proved the impact of sedimentation on marl and Shale erodible formations in Namak Lake of Iran [16]. The morphological specifications of the intended area reveal that the north part of the basin is totally in the ridge-valley mountainous unit and the southern parts are in Dezful embayment. In another word, two morphological zones can be marked in the water catchment: the northern mountainous zone and Dezful embayment zone .Parallel valleys and uprising parts along with Zagros characterize the northern mountainous zone. There are narrow valleys and other vast alluvia plains. The mountains are usually anticline. There are many blocks affecting the erosion of these walls and their fractures make soil fine grains and conglomerate blocks and increase sedimentation [17]. The outcrops of Bakhtiary conglomerate are found as long walls and very deep macro joints (more than $50-60 \mathrm{~m}$ ). There are dissolving pores in gypsum stones in the water catchment of Shur River at the depth of more than $15-20 \mathrm{~m}$. The stratigraphic units identified in the northern morphological zone are chronological as the following: Formations of Darian, Kazhdomi, Soruk, Gurpi, Pabdeh, Shahbazan or Taleh Zang, Amiran and Asmari have scored a widths of $3500 \mathrm{~m}$. Lime, shale and marl rock units have been alternatively made in these sedimentary units and ridge-valley structure is observed for the sake of their very different stratigraphic rock foundation [18]. The lime stones of the Asmari formation occupy almost more than half of the ridge-valley of Bakhtiary zone. The formation thickness reaches to $350-400 \mathrm{~m}$. The highest part of Asmari formation holds an alternation of lime stone and marl layers specifically in the north east side of Bala Ahmad anticline. The karst process is considered as one of the important remarks on Asmari formation. At the axial part of Baba Ahmad anticline, the Asmari lime stone layers are somehow horizontal and they have made 10 meter walls. Notably, the width of layers and looser marl or marl lime stone layers feature outa step like landmark. According to the lithology type and its looseness or hardness, some lithological units and formations are harder and some of them are looser. As a result, looser units affect sediment production and sedimentation the most [19]. Moreover, the type of the lithological units should be also considered. Marl limes or silica lime produce different sediments. Consequently, looser marl materials produce more sediments and harder silica materials produce less sediments [20]. Hence, fine grain sediments as size as silt and clay are made as the result of erosion, materials transportation and mal and silt marl 
layers of Aghajari and settled all along the river direction. Holistically, particles have been deposited as floating sedimentary load (clay-silt fine grains) and the rolling sedimentary load (as size of pebbles and sand).Land sliding phenomenon accumulates sediments at the bottom of mountains extension as deposits transported towards the lower parts because of erosion and weathering phenomenon in lithological formations and tectonic factors making fracture in lithological layers like joints and faults [21]. Table 3 displays the amount of erodability and sedimentation of the geological formations based on the lithology type in Lali Area, Khuzestan, Iran.

\section{Conclusions}

There is actually a collection of lithological units in this morphological zone called Fars Group including: Gachsaran, Mishan and Aghajari. Bakhtiary conglomerate is on these units aging back to Miocene-Pliocene. The units are as below: Gachsaran formation aging back to Miocene is situated in Zagros Mountains on the lime stone of Asmari formation. In this expansion, Mishan formation embraces gray marls which are highly affected by erosion and it doesn't have an outstanding outcrop, but some layers alternatively formed on Gachsaran formation In addition, Mishan formation or Gachsaran formation are mostly made of red clastic rocks with sand stone and conglomerate inter-beds called Aghajari aging back to Miocene-Pliocene. Bakhtiary conglomerate has two characteristics in this expansion: 1) Bakhtiary conglomerate has been placed on older rocks after orogeny. 2) Tectonic forces after forming Bakhtiary lithological unit only make some mild slopes and joints. In another word, other layers of Bakhtiary formations are almost horizontal. In fact, its outcrops are found everywhere on the highest topography parts of Dezful embayment. The geological situation of Taraz has been detected in these Bakhtiary conglomerate layers. There is an alluvial unit all through the

Table 3. The amount of erodability and sedimentation of the geological formations based on the lithology type in Lali Area, Khuzestan, Iran [22].

Lots of sediments (10)

$\begin{array}{ll}\text { Surface } & \text { - sea Shale } \\ \text { geology } & \text { - gypsum and Andesite content marls } \\ & \text { - the layers of stiff rocks and Shale } \\ & \text { - sandstones }\end{array}$

Lots of sediments (10)

- fine texture and highly dispersed, sore alkaline, high ability to expansion and compaction

- granular silt and fine gravel

- gravel

- gravel texture- Lummi made of granite

Moderate sediments (5)

Low sediments (0)

- moderate stiff rocks-metamorphic rocks

- crumpled or moderately weathered stones

- moderately fractured stones

- granites (igneous)

- fine limy stones

- dolomites

- conglomerate

- lime stone with thick layers

Moderate sediments (5)

Low sediments (0)

- moderate texture

- dispersed boulder

- limy layers

- pebble texture
- containing high percentage of boulder

- stiff textured clay

- containing high organic substances 


\section{Continued}

Lots of sediments (10)

- raining for some days with short cycles of thunder

Weather

- frequent heavy thunders

- dry climate with heavy rain

- run off of snow melting

Lots of sediments(10)

Run off

- high rate of discharge in surface

- high amount of water flow in surface

- hydrologic soils of group D

- hydrologic soils of group C

Lots of sediments (20)

The unpaved

areas

- deep slope areas more than $30 \%$

- high altitude, ups and downs

- slope beds

- flood resisting ups and downs

Lots of sediments (10)

Limited plant coverage

- land coverage less than $20 \%$

- dispersed plant coverage

- the lack of pebble on the ground

Lots of sediments (10)

Land usage $\quad$ the whole ground is like dispersed pasture

- the recently cut jungle coverage

- lots of road shears

High lands erosion

River erosion and sediment transportation
Moderate sediments (5)

Low sediments $(0)$

- moderate rainfalls

- frequent thunders

Moderate sediments (5)

- maximum moderate discharge

- moderate amount of run-off in surface

- hydrologic soils of group B

Moderate sediments (10) intensity

- mostly snowfall

- freezing and melting

- dry climate surface

- unique surface run off

- hydrologic soils of group A

Low sediments $(0)$
- wet climate and rainfalls with low

Low sediments $(0)$

- low amount of maximum discharge in

- low amount of run-off in surface

- plateau with moderate slope less than $20 \%$

- expansion of flood resisting areas with fan shaped physiographic units

- slow slope areas less than $5 \%$

- expanded alluvial plain

Moderate sediments (5)

Low sediments $(0)$
- ground coverage less than $40 \%$

- remarkable plant traces

- dispersed trees
- the ground surface completely covered by plants, more than $70 \%$ traces of plant and boulders

- low permeability of rain into erodible materials

Low sediments $(0)$
- more than $50 \%$ planted

- the plants recently burned

Lots of sediments (10)

- erosion plough, gally and a mass in more than $50 \%$ of the lands

- high amount of erosion

Lots of sediments (10)

- less than $25 \%$ planted

- less than $50 \%$ being extremely grazed

- less than $50 \%$ of the jungle coverage recently cut.

- the presence of usual roads and other constructions

Moderate sediments (5)

- the presence of various types of erosion in about $25 \%$ of the lands

- wind erosion with sedimentation in water canals

- moderate erosion

Moderate sediments (5)

- flow with depth and moderate continuity

- the erosion at the head and the decrease of their height with frequent erosion at the river side or river bed
- frequent erosion at the river side
- implantable land

- limited amount of grazing

- trees not recently cut

- with road or trails
- the absence of erosion signs

- low erosion
Low sediments (0)

- wide and low deep with flat slope of streams

- river bed on huge rock masses with boulders or with good plant coverage on the surfaces

- controlled streams 
expansion especially in Dezful embayment, and young and old alluvial sediments. Alluvia are usually in form of pebbles and coarse ones on rivers beds. The rivers' alluvia are also separated while flooding. Old alluvia have become flood plains at rivers banks. Their widths sometimes reach to several hundred meters. In conclusion, the oldest alluvia are changed into long and short alluvia terraces. These old alluvia look like large alluvial fans which have been smaller by erosion. Sediments are observed all around the extension of the heights. Remarkably, they sometimes cover the bed rocks of the formations. Sediments are accumulated in two forms of fine ones and stone blocks at the bottom of the long walls. The stone block deposits and fine grains have been expanded everywhere.

As a whole, the area's formations are different from one another according to the lithology type, layer material, erosion and sediment production and sedimentation. They are chronologically arranged. Pabdeh-Gurpi formation is made of shale and marl although it has low permeability and has high potential of erosion. Hence, it affects sedimentation the most.

Although lime stone is very hard, Asmari formation made of lime stone to marl lime has the characteristic of karst. Gachsaran formation made of gypsum has the ability to be solved and weathered. It can also produce sediment. Bakhtiary conglomerate is mainly hard and compacted and it doesn't have a remarkable ability to make erosion and produce sediment.

Conclusively, Pabdeh-Gurpi and Gachsaran formations are more able to produce sediments, while Asmari and Bakhtiary conglomerate affects sedimentation the least and Aghajari formation is in between. The quaternary alluvia can be transported and settled. Results specify that it is essential to scrutinize and identify the types of formations and lithological units of the upstream and the banks of the dams' reservoirs in civil projects and dam construction studies in order to find out better alternatives against sediments made by the erosion of these soil-lithological units. It is recommended to plant trees, establish berm, reduce topography slope and choose more suitable methods to control water in order to decline erosion and sedimentation.

\section{Suggestions}

Regarding the studies and observations in erosion phenomenon, sedimentation and sediment accumulation in geological formations the following items are suggested.

In situation of geological formations with the potential of sedimentation and erodability, there should be given a good consideration on investigations of the amount of sediment production in the geological formations situated in water catchments directing into identifying formations ready to be eroded. Presenting factors affecting the erosion process is led into selecting the most convenient methods to diminish the effect of these processes and control its harmful effects in the intended area before starting any civil project specially dam construction studies. Basic studies on the amount of sediment taken from the geological are directed into the increase of sedimentary load entering into reservoirs. Proper alternatives are taken to reduce its harmful effects 
through analyzing the data of these studies.

\section{Acknowledgements}

The authors acknowledge Dr. Ali Solgi, the head master of geology department of Islamic Azad University of Science and Research of Tehran, Eng. M.H Nabavi and Dr. Hussein Jalali, the managers of Ab-Niru Company, and all the ones who contributed us to prepare this research.

\section{References}

[1] Stocklin, J. and Setudehnia, A. (1971) Stratigraphic Lexicon of Iran. Part 1: Central, North and East Iran. Geological Survey of Iran, Report No. 18, 376 p.

[2] Nabavi, M.R. (2005) Report on General Geology and Engineering of Taraz Dam, Ab-Niru Consultant Engineers Company, Tehran.

[3] Simon, D.B., et al. (1977) Sediment Transport Technology. Water Resources Publications, Front Collins, Colorado.

[4] Nolan, K.M., Janda, R.J. and Galton, J.H. (1986) Sediment Source and Sediment-Transport Curves. Processing of the 4th Federal Interagency Sedimentation Conference, 1, 4-79.

[5] Kasimir, M., Besar, I. and Sowa, A. (1995) Influence of Geology of Erosion and Sediment Yield. Human Activities of the Environment in Selected Areas in Southern Nigeria, Sixth International Symposium on River Sediment, New Delhi, India.

[6] Khojeini, A. and Nezhadhashemi, M.A. (1998) A Study on Sediment Production in Taleghan Watershed. Pazhuhesh and Sazandegi, 10-13, 39.

[7] Ghadimi Arusmahalleh, F., et al. (1998) Analyzing the Floating Sediments in Namak Lake Watershed. Pazhuhesh and Sazandegi, No. 45.

[8] Aminsobhani, F., et al. (1998) A Study on Zones' Sedimentation and Geological Eras in Namak Lake Watershed. Pazhuhesh and Sazandegi, 36-41, 39.

[9] Veatot, D., et al. (2005) Predicting Soil Erosion and Sediment Field at the Basic Scale Issue and Sediment-Quantitatine Models. Earth Science Reviews, 71, 95-125. http://dx.doi.org/10.1016/j.earscirev.2005.02.002

[10] Schwab, G., et al. (1981) Soil and Water Conservation Engineering. John Wiley Inc., New York.

[11] Yang, C.T. (1977) The Movement of Sediment in Rivers. Geophysical Survey, 3, 39-68. http://dx.doi.org/10.1007/BF01449182

[12] Parker, G. (1990) Surface Based Bed Load Transport Relationship for Gravel Rivers. Journal of Hydraulic Research, 28, 417-436. http://dx.doi.org/10.1080/00221689009499058

[13] Feiznia.S. (1995) Rocks Resistance against Erosion in Different Climates of Iran. Journal of Natural Resources, 47, 95-116.

[14] Rahimzadeh, F. (1994) Geology of Iran, Oligocene, Miocene, Pliocene Geological Plan of the Book. Number 12, the Ministry of Mines and Metals, the Country's Geological Survey, 153-170.

[15] Lasemi, Y., et al. (2000) Sedimentary Environments and Sequence Stratigraphy of the Upper Precambrian and Paleozoic Deposits of Iran. Geological Survey of Iran, Tehran, 180.

[16] Issler, D.R. (1992) A New Approach to Shale Compaction and Stratigraphic Restoration, Beaufrt-Macken Zie Basin and Mackenzie Corridor, Northern Canada. AAPG Bulletin, 76, 1170-1189. 
[17] William, A. (2007) Erosion and Sedimentation. The Gale Group Inc., New York.

[18] Parker, G. (1990) Surface Based Bed Load Transport Relationship for Gravel Rivers. Journal of Hydraulic Research, 28, 417-436. http://dx.doi.org/10.1080/00221689009499058

[19] Hills, R.R. (1993) Quantifying Erosion in Sedimentary Basins from Sonic Velocity in Shale and Sandstone. Exploration Geophysics, 24, 561-566.

[20] Hassanvand, A. and Aleali, M. (2009) Study of Lithofacies, Microfacies and Depositional Environment of Asmari Formation in Parsi Oil Field. Journal of Sediment and Sedimentary Rock, 2, 82-73.

[21] Olowokere, M.T. and Ojo, J.S. (2011) Porosity and Lithology Prediction in Eve Field, Niger Delta Using Compaction Curves and Rock Physics Models. Open Journal of Geology, 2, 366-372. http://dx.doi.org/10.4236/ijg.2011.23039

[22] Alijani, A.R., et al. (2016) Evaluating the Amount of Erodability and Sedimentation by Comparing Sediment Weight Model and PSIAC Experimental Model (Case Study: Lali Water Catchment, Khuzestan, Iran). Open Journal of Geology, 6, 691-702.

http://dx.doi.org/10.4236/ojg.2016.68053

Submit or recommend next manuscript to SCIRP and we will provide best service for you:

Accepting pre-submission inquiries through Email, Facebook, LinkedIn, Twitter, etc. A wide selection of journals (inclusive of 9 subjects, more than 200 journals)

Providing 24-hour high-quality service

User-friendly online submission system

Fair and swift peer-review system

Efficient typesetting and proofreading procedure

Display of the result of downloads and visits, as well as the number of cited articles Maximum dissemination of your research work

Submit your manuscript at: http://papersubmission.scirp.org/ 